\title{
COMMENTS
}

\section{SIMPLICITY AT THE COST OF CLARITY: APPELLATE REVIEW OF CLAIM CONSTRUCTION AND THE FAILED PROMISE OF CYBOR}

\section{WILLIAM H. BURGESS ${ }^{\dagger}$}

In its en banc ruling in Cybor Corp. v. FAS Technologies, Inc., ${ }^{1}$ the Federal Circuit attempted to settle much of the confusion surrounding appellate review of claim construction with a simple bright-line rule-it declared that claim construction is a pure matter of law with no underlying factual inquiries, and therefore reviewable de novo on appeal. In the years leading up to Cybor, the federal district courts were struggling to apply the Federal Circuit's rules on claim construction, and the Federal Circuit and the district courts were struggling to parse the issues of fact and law implicated in claim construction. The promise of Cybor was in its simplicity. No longer would the district courts have to separate issues of law and fact in claim construction, and by securing de novo review the Federal Circuit would be freer to lead by example and could ensure consistency and uniformity in claim construction by taking the issue for itself. Further, the Cybor ruling has been understood as wholly consistent with the Supreme Court's prior decision on claim construction in Markman v. Westview Instruments, Inc. ${ }^{2}$

In this Comment, I argue that, counterintuitively, the bright-line rule drawn by Cybor has resulted in a great deal of inconsistency in the Federal Circuit's claim construction jurisprudence. The reason for this, I argue, is that certain issues underlying claim construction are

\footnotetext{
${ }^{\dagger}$ J.D. expected 2005, University of Pennsylvania Law School; B.E. 2002, Thayer School of Engineering; A.B. 2001, Dartmouth College. I am extremely grateful to R. Polk Wagner and Edward R. Reines, who provided suggestions and thoughtful criticism throughout the writing process and contributed greatly to my understanding of patent law. Thanks also to Herbert Schwartz and Robert Ballenger for reviewing earlier drafts of this Comment. Any errors and all opinions expressed herein are mine alone.

138 F.3d 1448 (Fed. Cir. 1998).

2517 U.S. 370 (Markman II) (1996).
} 
immutably questions of fact rather than law. Once the Federal Circuit made a rule that required it to force fact questions to behave as pure legal issues, the rule became difficult to apply consistently, and had four principal effects: (1) in some cases the rule was impossible to apply without strained logic, such as remands for "lawfinding"; (2) some judges have partially defected and been lax in their application of the rule; (3) the Cybor rule began infecting other areas of patent law and blurring the line between fact and law issues by analogy to claim construction; and (4) these first three results have led to confusion at the district court level. Further, I argue, the Cybor decision is best understood as either tangential to, or inconsistent with, the Supreme Court's Markman decision.

This Comment is in four parts. Part I provides background information on the issues discussed here. Part II discusses the doctrinal inconsistency between Cybor and Federal Circuit and Supreme Court precedent. Part III traces the effects of the Cybor rule on the Federal Circuit's jurisprudence. Finally, the Comment concludes with a call for the Federal Circuit either to overrule Cybor and seek uniformity in claim construction through less drastic bright-line rules that focus on the process of claim construction itself, or to scale back Cybor and acknowledge that it reviews claim construction de novo on appeal because of a useful legal fiction. To the extent that the Federal Circuit has given itself the opportunity to reconsider Cybor when it hears Phillips v. AWH Corp. en banc, ${ }^{3}$ it should do so with regard for the issues addressed here.

\section{BACKGROUND ON THE FEDERAL CiRCUIT, Claim CONSTRUCTION, AND CYBOR}

\section{A. The Federal Circuit}

The United States Court of Appeals for the Federal Circuit (Federal Circuit) is likely the most influential actor in the system of patent law, ${ }^{4}$ and has exclusive jurisdiction over all appeals from patent cases

\footnotetext{
${ }^{3} 363$ F.3d 1207 (Fed. Cir. 2004), reh'g en banc granted, 376 F.3d 1382 (Fed. Cir. 2004) (per curiam).

${ }^{4}$ This is true for many reasons, including that the Supreme Court has granted certiorari on very few patent cases since the creation of the Federal Circuit, and has taken a very hands-off approach to patent law. See generally John F. Duffy, The Festo Decision and the Return of the Supreme Court to the Bar of Patents, 2002 SUP. CT. REV. 273, 277 (describing the Supreme Court's "continued retreat from patent law"); Mark D. Janis, Patent Law in the Age of the Invisible Supreme Court, 2001 U. ILL. L. REV. 387, 387-88 (discuss-
} 
in the federal district courts and from final decisions of the United States Patent and Trademark Office (PTO). ${ }^{5}$ Congress created the Federal Circuit in $1982,{ }^{6}$ largely in response to concerns about the state of patent law in the regional circuits, most notably a lack of intercircuit uniformity and a lack of deference to the findings of the PTO. ${ }^{7}$ By 1982, different regional circuits had developed disparate reputations for being particularly favorable or unfavorable to patentees, resulting in a great deal of forum shopping. ${ }^{8}$ Further, the lack of deference to the PTO's determinations of patentability cheapened the general value of patents because of the increased likelihood that patents would be invalidated in litigation. ${ }^{9}$ Congress gave the Federal

ing the Supreme Court's "benchwarmer status in the patent system" and referring to the Federal Circuit as the "supreme court of patents"); $c f$. Warner-Jenkinson Co. v. Hilton Davis Chem. Co., 520 U.S. 17, 39 n.8 (1997) ("We leave it to the Federal Circuit how best to implement procedural improvements to promote certainty, consistency, and reviewability to this area of the law [the intersection of the doctrine of equivalents, prosecution history estoppel, and dealing with juries].").

${ }^{5} 28$ U.S.C. $\$ 1295$ (a) (1)-(4) (2000). The remainder of $\$ 1295$ further gives the Federal Circuit exclusive jurisdiction over appeals from the Board of Contract Appeals, the Court of International Trade, the Court of Federal Claims, the International Trade Commission, and the Merit Systems Protection Board. The Supreme Court has recently undercut this exclusivity with its decision in Holmes Group, Inc. v. Vornado Air Circulation Sys., Inc., 535 U.S. 826 (2002) (holding that the Federal Circuit does not have appellate jurisdiction over an appeal in which the complaint did not state a claim arising under the patent laws, although the counterclaims did).

${ }^{6}$ Federal Courts Improvement Act of 1982, Pub. L. No. 97-164, 96 Stat. 25 (codified in scattered sections of 28 U.S.C.). The Federal Circuit began work on October 1, 1982. The Federal Courts Improvement Act formed the Federal Circuit by merging the preexisting Court of Customs and Patent Appeals and the Court of Claims. In its first opinion, South Corp. v. United States, 690 F.2d 1368, 1370 (Fed. Cir. 1982) (en banc), the Federal Circuit adopted the precedents of its two predecessors. For an extended discussion of the origins and early history of the Federal Circuit, see THE United States Court of ApPeals for the Federal Circuit: A History 1982-1990, at 1-16 (1991) [hereinafter FEDERAL CiRCUIT HistoRY].

${ }^{7}$ See Rochelle Cooper Dreyfuss, The Federal Circuit: A Case Study in Specialized Courts, 64 N.Y.U. L. REV. 1, 6-7 (1989) (noting that these problems were highlighted by the congressional Hruska Commission in the early 1970s).

${ }^{8}$ See H.R. REP. No. 97-312, at 20-22 (1981) (describing the prevalence of forum shopping in patent litigation); Dreyfuss, supra note 7 , at 7 ("[F]orum shopping was rampant, and ... a request to transfer a patent infringement action from Texas, in the Fifth Circuit, to Illinois, in the Seventh Circuit, would be bitterly fought ....”). Professor Mossinghoff recounts a story in which Thurgood Marshall, during an interview to prepare him for his Supreme Court confirmation hearing in 1967, responded to a question with the quip, "I haven't given patents much thought, Senator, because I'm from the Second Circuit and as you know we don't uphold patents in the Second Circuit." Hon. Gerald J. Mossinghoff, Side Bar: The Creation of the Federal Circuit, in PRINCIPLES OF PATENT LAW 30, 31 (Donald S. Chisum et al. eds., 2d ed. 2001).

${ }^{9}$ See Federal Circuit History, supra note 6, at 10 (noting that this problem of- 
Circuit exclusive jurisdiction over patent appeals to solve these problems and to bring greater uniformity to patent law. ${ }^{10}$ For reasons of efficiency, and to alleviate concern that the Federal Circuit would become too narrowly specialized and develop an institutional bias, ${ }^{11}$ the Federal Circuit was also given responsibility for appeals from various administrative and specialty courts (e.g., the Court of Veterans' Appeals). ${ }^{12}$

As the lone appellate court in the federal system whose jurisdiction is based on subject matter rather than geography, the Federal Circuit is a sustained experiment, ${ }^{13}$ and its unique aspects raise questions about whether it should fill the same role in the federal court system as the regional circuits, relative to the district courts and the Supreme Court. Professor Rochelle Cooper Dreyfuss wrote the seminal article on the Federal Circuit in $1989 .{ }^{14}$ In the article, she assessed the court's performance over the previous years, predicted some of its challenges for the future, and argued that its most significant overall challenge would be "to develop a concept of itself as a court." ${ }^{\text {"15 }}$ Professor Dreyfuss noted that the Federal Circuit's superior expertise and experience in patent law strained the assumption underlying Rule 52(a) of the Federal Rules of Civil Procedure ${ }^{16}$ - that district courts are in a better position to decide factual issues. ${ }^{17}$ Rule 52(a)'s requirement of deference to factual findings of trial courts also "puts pressure

ten combined with the disparity among the regional circuits to create a "high-risk game of forum-shopping").

${ }^{10}$ See Craig Allen Nard, Process Considerations in the Age of Markman and Mantras, 2001 U. ILL. L. REV. 355, 356 (arguing that "uniformity" and "certainty" have recently "achieved mantra status").

${ }^{11}$ See Federal Circuit History, supra note 6, at 12-13 (describing the reasoning behind the legislation that created the Federal Circuit).

${ }^{12} I d$.

${ }^{13}$ See Dreyfuss, supra note 7, at 3 (referring to the Federal Circuit as a "sustained experiment in specialization").

${ }^{14} I d$.

${ }^{15} I d$. at 5 .

${ }^{16}$ FED. R. CIV. P. 52(a) provides in relevant part that

[i] $\mathrm{n}$ all actions tried upon the facts without a jury or with an advisory jury, the court shall find the facts specially and state separately its conclusions of law thereon .... Findings of fact, whether based on oral or documentary evidence, shall not be set aside unless clearly erroneous, and due regard shall be given to the opportunity of the trial court to judge of the credibility of the witnesses.

${ }^{17}$ Dreyfuss, supra note 7 , at 48 ("Where ... the trial court is composed of generalists and the appellate court is staffed to deal with the complex factual issues being tried, the assumption breaks down, for the appellate court is at least as well situated to find the facts as the trial court."). 
on the distinction between fact and law." ${ }^{18}$ Thus, the article stated, the challenge to the Federal Circuit in developing a concept of itself as a court would include the resolution of procedural issues ${ }^{19}$ and finding "some method for reversing [district court] decisions that it believes are unresponsive to the spirit of its teachings." ${ }^{20}$ The article seems to have accurately predicted the future of the Federal Circuit in this regard, for one of the procedural issues that has risen to great importance recently is the Federal Circuit's review of claim construction. This Comment argues that, through its decision in Cybor, the Federal Circuit has found a way to reverse district court decisions that are unresponsive to its teachings, but has done so in a way that has clouded the clarity of its teachings.

\section{B. Claim Construction}

Claim construction is probably the most important issue in patent infringement litigation. ${ }^{21}$ Like the interpretation of a statute or a contract, claim construction is the process by which a court determines the meaning of the words in a patent claim for the purposes of the litigation. This is important because the scope of an inventor's patent, and consequently her right to sue others for infringement, is determined entirely by the meaning that the court gives to the claims of the patent document, not by the physical invention, the history of the inventive process, or anything else filed in the patent office. ${ }^{22}$

When an inventor files for a patent, her application must include: (1) a written description of the invention, including a description of the field (e.g., chemistry, circuit design, microbiology, etc.), a description of the prior art, and a detailed description of the invention that the inventor seeks to patent; ${ }^{23}$ (2) drawings of the invention, if neces-

${ }^{18} I d$.

19 Id. at 61-63.

${ }^{20} I d$. at 50.

21 See, e.g., John F. Duffy, On Improving the Legal Process of Claim Interpretation: Administrative Alternatives, 2 WASH. U. J.L. \& POL'Y 109, 109 (2000) (noting that claim interpretation is "frequently the central issue in infringement litigation").

${ }^{22}$ See, e.g., Gen. Foods Corp. v. Studiengesellschaft Kohle mbH, 972 F.2d 1272, 1274 (Fed. Cir. 1992) (explaining that the claims of the patent document "define or delimit the scope of the legal protection which the government grant gives the patent owner, the patent 'monopoly"”). The prosecution history, physical embodiments, and other "extrinsic evidence" may affect the meaning that the court gives to the claims, but it is the claims, as construed by the court, that determine the scope of an inventor's right to sue for infringement.

2335 U.S.C. $\$ 112(2000)$. 
sary; ${ }^{24}$ and (3) claims. ${ }^{2.5}$ In the claims portion of the application, the inventor cabins the scope of the patent by "particularly pointing out and distinctly claiming the subject matter which the applicant regards as his invention." ${ }^{26}$ When an inventor accuses another of infringing her patent, the question of infringement hinges on whether the accused infringer's device contains "all elements" of the patent claim that is allegedly infringed. ${ }^{27}$ Thus, if an inventor were to claim "a writing implement comprising: (a) a wooden cylinder with a hollow core, (b) a cylinder of graphite in said hollow core, and (c) a small cylinder of eraser material attached to one end of the wooden cylinder," a typical wooden pencil with a metal shirt-pocket clip added to it would literally infringe the claim because it contains all three elements of the claim, while a typical pencil without an eraser would not, because it lacks element $(\mathrm{c}){ }^{28}$

Most patent infringement trials, however, involve technology more complex than wooden pencils, and the first step of any patent infringement trial is for the trial court to read the patent claims and determine their meaning. ${ }^{29}$ Once the trial court construes the claims, the next step is to compare the claims to the accused device. ${ }^{30}$ It often happens that the trial court's claim construction either clearly does or does not encompass the infringer's device, and it becomes unnecessary to proceed further to the question of infringement. Judge Mayer has asserted that "to decide what the claims mean is nearly always to

${ }^{24} I d$. at $\$ 113$.

${ }^{25} I d$. at $\$ 112$ para. 2.

${ }^{26} I d$.

${ }^{27}$ See, e.g., Lemelson v. United States, 752 F.2d 1538, 1551 (Fed. Cir. 1985) ("It is ... well settled that each element of a claim is material and essential, and that in order for a court to find infringement, the plaintiff must show the presence of every element or its substantial equivalent in the accused device.").

${ }^{28}$ This example is borrowed from Professor R. Polk Wagner, Introduction to Intellectual Property Law, Course at the University of Pennsylvania Law School (Spring 2003), available at http://www.law.upenn.edu/polk/ip/2003sp/downloads/notes.03. 17.ppt.pdf (last accessed Nov. 4, 2004).

${ }^{29}$ See Merck \& Co. v. Teva Pharm. USA, Inc., 347 F.3d 1367, 1369 (Fed. Cir. 2003) ("In determination of patent infringement, as the first step the claims are construed; then, the construed claims are compared to the alleged infringing device."); Caterpillar Tractor Co. v. Berco, S.p.A., 714 F.2d 1110, 1114 (Fed. Cir. 1983) ("Determination of patent infringement requires two steps: the meaning of the claims must be learned from a study of all relevant patent documents; and the claims must be applied to the accused structures.”).

${ }^{30}$ The trial court's claim construction is also instrumental to many of the affirmative defenses and counterclaims commonly asserted in patent litigation, such as obviousness and anticipation by prior art. 
decide the case." ${ }^{31}$ Unfortunately, claim construction is a complicated and contentious process, and recent studies have shown that district courts' claim constructions are reversed by the Federal Circuit in as many as forty percent of the appeals in which the issue arises. ${ }^{32}$

\section{Markman and Cybor and the Federal Circuit's Review of Claim Construction}

In its review of claim construction, as with all other issues appealed from the district courts, the Federal Circuit is constrained by Rule 52(a) of the Federal Rules of Civil Procedure, and is thus bound to defer to the district courts on issues of fact. ${ }^{33}$ Although the Federal Circuit's special expertise puts pressure on this notion of deference, ${ }^{34}$ the Panduit cases, spanning from 1985 through 1987, established that Rule 52(a) applies equally to the Federal Circuit as to the regional circuits.

In 1985, in Panduit Corp. v. Dennison Manufacturing Co., the Federal Circuit considered the issue of obviousness and reversed the district judge's findings. ${ }^{35}$ The Supreme Court granted certiorari and, in a short opinion, stated that the factual inquiries underlying a determination of obviousness should be subject to the clear error standard under Rule 52(a). ${ }^{36}$ However, the Supreme Court indicated that it might be receptive to an explanation that Rule 52(a) somehow did

${ }^{31}$ Markman v. Westview Instruments, Inc. (Markman I), 52 F.3d 967, 989 (Fed. Cir. 1995) (en banc) (Mayer, J., concurring), aff'd, 517 U.S. 370 (1996).

${ }^{32}$ See Cybor Corp. v. FAS Techs., Inc., 138 F.3d 1448, 1476 \& n.4 (Fed. Cir. 1998) (Rader, J., dissenting in part) (referring to Federal Circuit statistics showing that, since Markman I was decided, the Federal Circuit had reversed nearly $40 \%$ of claim constructions on appeal); see also Christian A. Chu, Empirical Analysis of the Federal Circuit's Claim Construction Trends, 16 BERKELEY TECH. L.J. 1075, 1104 (2001) (observing that "the Federal Circuit reversed $29.6 \%$ of cases involving an express review of claim construction" during the period from January 1998 through April 2000); Kimberly A. Moore, Are District Court Judges Equipped to Resolve Patent Cases?, 15 HARV. J.L. \& TECH. 1, 8-11 (2001) (finding an error rate of $33 \%$ in district court claim construction).

${ }^{33}$ See FED. R. CIV. P. 52(a) ("Findings of fact... shall not be set aside unless clearly erroneous ....").

${ }^{34}$ See supra notes 13-20 and accompanying text (detailing the sources of this tension).

${ }^{35} 774$ F.2d 1082, 1102 (Fed. Cir. 1985), vacated by 475 U.S. 809 (1986) (per curiam).

${ }^{36}$ See Dennison Mfg. Co. v. Panduit Corp., 475 U.S. 809, 811 (1986) (per curiam) (quoting Graham v. John Deere Co. of Kansas City, 383 U.S. 1, 17-18 (1966)) (describing obviousness as a determination that "lends itself to several basic factual inquiries" and holding that "the subsidiary determinations of the District Court, at the least, ought to be subject to the Rule"). 
not apply in that case ${ }^{37}$ and remanded the case to the Federal Circuit for "consideration in light of Rule 52(a).", On remand, the Federal Circuit panel did not challenge the applicability of Rule 52(a), but stated instead that it had applied Rule 52(a) faithfully in the past, ${ }^{39}$ and restated its obviousness analysis more clearly. The result was that obviousness was labeled a conclusion of law that is based on underlying factual inquiries, and the Federal Circuit essentially reiterated a mixed standard of review for obviousness. "Like all legal conclusions," the panel stated, "[the legal conclusion] under $§ 103$ rests on a factual evidentiary foundation." ${ }^{40}$ The Panduit cases further established that a mixed standard of review, in which the Federal Circuit reviews legal conclusions de novo and factual inquiries underlying the legal conclusions for clear error, necessarily follows from Rule 52(a). After the Panduit cases, the Federal Circuit seemed content to stick to the mixed standard of review, and applied it to many of the issues in pat-

${ }^{37}$ See id. ("The Federal Circuit... did not explain why, if it was of that view, Rule 52 (a) had no applicability to this issue.... [W] e lack the benefit of the Federal Circuit's informed opinion on the complex issue of the degree to which the obviousness determination is one of fact.").

${ }^{38} I d$.

${ }^{39}$ See Panduit Corp. v. Dennison Mfg. Co., 810 F.2d 1561, 1568-69 (Fed. Cir. 1987) ("Graham, Anderson, Rule 52(a), and the clearly erroneous standard have, before the remand, been consistently applied by this court in affirming judgments that upheld a patent and judgments that struck down a patent." (footnote omitted) (referring to Anderson v. Bessemer City, 470 U.S. 564 (1985); Graham, 383 U.S. at 1)). In another part of the opinion that reflects the extent to which Rule 52(a) kept the Federal Circuit from reversing as many opinions as it would like, Chief Judge Markey stated that "[t]o contribute to consistency in construing $\S 103$ [obviousness], this court has affirmed judgments while noting noncontrolling misstatements of law and cautioning counsel that judgments are appealed, not opinion language." Id. at 1567.

Id. at 1567 . 
ent litigation, including obviousness, ${ }^{41}$ inventorship, ${ }^{42}$ enablement, ${ }^{43}$ and applicability of the on-sale bar. ${ }^{44}$

Claim construction, like the issues noted above, is a legal conclusion. The Federal Circuit debated for many years whether claim construction involves underlying factual inquiries, and if so, what the implications of those inquiries would be for infringement trials and appellate review. Before 1995, no case had squarely addressed whether there was ever a right to have claim construction tried to a jury, nor had any case addressed whether claim construction was a pure issue of law or a legal conclusion with underlying factual inquiries. In Markman $I,{ }^{45}$ which came before the court in 1995, the Federal Circuit addressed en banc the issue of whether claim construction must be tried to a jury. The district court judge, reversing the jury verdict and entering judgment as a matter of law, decided that claim construction was a matter of law for the courts and that "[a] mere dispute concerning the meaning of a term does not itself create a genuine issue of material fact." ${ }^{46}$ The plaintiff, Herbert Markman, appealed, arguing inter alia that his testimony and his expert's testimony raised a question of fact as to the construction of the claims, and that deference was there-

${ }^{41}$ See, e.g., Weatherchem Corp. v. J.L. Clark, Inc., 163 F.3d 1326, 1332 (Fed. Cir. 1998) ("[T] his court reviews an obviousness invalidation without deference. That determination, too, however, invariably rests on factual underpinnings that this court reviews, if disputed, for clear error." (citation omitted)); Panduit, 810 F.2d at 1569 (describing a mixed standard of review) .

${ }^{42}$ See, e.g., Ethicon, Inc. v. U.S. Surgical Corp., 135 F.3d 1456, 1460 (Fed. Cir. 1998) ("Inventorship is a question of law .... However, this court reviews the underlying findings of fact which uphold a district court's inventorship determination for clear error." (citation omitted)).

${ }^{43}$ See, e.g., Enzo Biochem, Inc. v. Calgene, Inc., 188 F.3d 1362, 1369 (Fed. Cir. 1999) ("[W] hether a disclosure is enabling under 35 U.S.C. $§ 112$, I 1, is a question of law that we review de novo, based on underlying factual inquiries that we review for clear error.").

${ }^{44}$ See, e.g., Manville Sales Corp. v. Paramount Sys., Inc., 917 F.2d 544, 549 (Fed. Cir. 1990) ("Whether or not an invention was on sale or in public use within the meaning of section 102(b) is a question of law that this court reviews de novo; however, factual findings underlying the trial court's conclusion are subject to the clearly erroneous standard of review."). Obviousness, improper designation of inventorship, lack of enablement, and applicability of the statutory on-sale bar are all defenses to patent infringement claims, and frequently arise as counterclaims in patent cases.

${ }_{45}$ Markman I, 52 F.3d 967 (Fed. Cir. 1995) (en banc).

${ }^{46}$ Markman v. Westview Instruments, Inc., 772 F. Supp. 1535, 1536 (E.D. Pa. 1991) (quoting Becton Dickinson \& Co. v. C.R. Bard, Inc., 922 F.2d 792, 797 (Fed. Cir. 1990)). 
fore due the jury's claim construction. ${ }^{47}$ The Federal Circuit affirmed the district court, stating that:

We therefore settle inconsistencies in our precedent and hold that in a case tried to a jury, the court has the power and obligation to construe as a matter of law the meaning of language used in the patent claim. As such, "[a] patent covers the invention or inventions which the court, in construing its provisions, decides that it describes and claims." Because claim construction is a matter of law, the construction given the claims is reviewed de novo on appeal. ${ }^{48}$

The Supreme Court granted certiorari on the narrow issue of whether the Seventh Amendment requires claim construction to be tried to a jury, ${ }^{49}$ and unanimously held that it did not. ${ }^{50}$ The Court looked to history and its own precedent and found that, although neither interpretive source provided a clear answer, there was scant evidence showing that judges ordinarily construed patent documents ${ }^{51}$ and no evidence supporting a right to have claim construction tried to a jury. "Where history and precedent provide[d] no clear answers," the Court turned to what it termed "functional considerations," ${ }^{, 52}$ and ultimately held that, because judges were better qualified than juries to construe claims and because allocating the issue to judges would better serve the purpose of uniformity, "the construction of a patent, including terms of art within its claim, is exclusively within the province of the court. ${ }^{, 53}$

Because the Supreme Court's decision resolved only the narrow issue of whether the Seventh Amendment requires that claim construction be tried to a jury, the ensuing two years were marked by disagreement among the judges of the Federal Circuit as to whether deference is ever due, under Rule 52(a), to district courts' claim

${ }^{47}$ Markman I, 52 F.3d at 974.

${ }^{48} I d$. at 979 (alteration in original) (citation omitted).

${ }^{49}$ See Markman v. Westview Instruments, Inc. (Markman II), 517 U.S. 370, 372 (1996) ("The question here is whether the interpretation of a so-called patent claim ... is a matter of law reserved entirely for the court, or subject to a Seventh Amendment guarantee that a jury will determine the meaning of any disputed term of art about which expert testimony is offered.").

${ }^{50} I d$. at 391 .

${ }^{51}$ See id. at 382 ("[A]s soon as the English reports did begin to describe the construction of patent documents, they show the judges construing the terms of the specification."). The Court reasoned by analogy to patent specifications, because claims as such were not required in patent applications until 1870. Id. at 379 (citing Act of July 8,1870 , ch. $230, \S 26,16$ Stat. 201).

${ }^{52}$ Id. at 388 .

${ }^{53} I d$. at 372 . 
constructions. The Federal Circuit took the issue en banc in 1998, and a nine-judge majority held that "as a purely legal question, we review claim construction de novo on appeal including any allegedly factbased questions relating to claim construction," ${ }^{, 54}$ and stated repeatedly that claim construction is a purely legal issue. Cybor thus drew a bright-line rule in the sense that it simplified appellate review of claim construction. This Comment argues that Cybor's seemingly simple rule has in fact clouded the clarity of the Federal Circuit's jurisprudence and made it more difficult for the district courts to apply its rules consistently.

The Federal Circuit recently granted rehearing en banc in Phillips v. $A W H$ Corp. $^{55}$ to resolve several questions about how it performs claim construction. Most of the issues that the court selected for en banc resolution relate to the bifurcation of the court's methodology, ${ }^{56}$ and to the role of dictionaries and other interpretive sources in the claim construction process. The final question in the order, however, suggests that the court may be willing to address an aspect of its holding in Cybor. The court asked:

Consistent with the Supreme Court's decision in [Markman II], and our en banc decision in [Cybor], is it appropriate for this court to accord any deference to any aspect of trial court claim construction rulings? If so, on what aspects, in what circumstances, and to what extent?

While this slight reopening of Cybor is promising, Chief Judge Mayer pointed out in dissent that the court phrased the question as a desire to clarify the holding of Cybor, not to reconsider it or to address the questions of whether and to what extent claim construction may be based on questions of fact. Chief Judge Mayer characterized the en banc order as a mere "shuffling [of] our current precedent," stated that " $[\mathrm{u}]$ ntil the court is willing to reconsider its holdings in [Markman I and Cybor] that claim construction is a pure question of

${ }^{54}$ Cybor Corp. v. FAS Techs., Inc., 138 F.3d 1448, 1456 (Fed. Cir. 1998) (en banc). Chief Judge Mayer and Judges Rader and Newman dissented in part in Cybor and also wrote separately in Markman I to take issue with this characterization of claim construction. See infra note 64.

55376 F.3d 1382 (Fed. Cir. 2004) (per curiam).

${ }^{56}$ See generally infra note 92 (discussing what some scholars have termed the "procedural" approach to claim construction).

${ }^{57}$ Phillips, 376 F.3d at 1383.

${ }^{58}$ Id. at 1384 (Mayer, C.J., dissenting). 
law subject to de novo review in this court, any attempt to refine the process is futile. ${ }^{59}$

\section{THE DOCTRINAL INCONSISTENCY OF CYBOR}

This Part argues that Cybor was wrongly decided in light of prior Federal Circuit precedent and the Supreme Court's decision in Markman II. By 1998, the Federal Circuit had developed a body of case law on claim construction that, while imperfect, still sent a few clear messages to the district courts. By indirectly contradicting many of these messages, the Federal Circuit clouded the clarity of its case law.

\section{A. Inconsistency with the Supreme Court- The Cybor and Markman Decisions}

Cybor is inconsistent with the Supreme Court's holding in Markman II, first because it goes beyond the scope of Markman II and directly contradicts some of Markman II's reasoning, and second because its approach to the fact/law distinction is at odds with the Supreme Court's teachings in Markman II. Rather than classifying claim construction along the lines of fact and law, the holding of Markman II rested on policy grounds, and the Cybor majority seems to have ignored this important point. Because of the timing of the deci$\operatorname{sion}^{60}$ and the fact that it construed a Supreme Court opinion, the rule it announced had the combined weight of an en banc opinion and the appearance of the imprimatur of the Supreme Court.

Several commentators have noted that Cybor went beyond the scope of the holding of Markman $I{ }^{61}$ and the concurring and dissenting judges in Cybor criticized the majority opinion as an overbroad in-

${ }^{59}$ Id.

${ }^{60}$ The Supreme Court decided Markman II on April 23, 1996, Markman II, 517 U.S. at 370, and less than seventeen months later, on September 7, 1997, the Federal Circuit decided, sua sponte, to hear Cybor en banc, Cybor, 138 F.3d at 1451. Thus, before divergent panel interpretations had a chance to develop momentum, the Federal Circuit had the rare opportunity to write the definitive interpretation of a Supreme Court opinion.

61 See, e.g., Moore, supra note 32, at 29 (noting that after Markman II, the Federal Circuit in Cybor resolved the standard of review controversy in favor of de novo review); Arti K. Rai, Engaging Facts and Policy: A Multi-Institutional Approach to Patent System Reform, 103 COLUM. L. REv. 1035, 1048 n.49 (2003) (suggesting that the Federal Circuit went beyond the Supreme Court's Markman II holding); Matthew R. Hulse, Note, Cybor Corp. v. FAS Technologies, Inc., 14 BERkELEY TECH. L.J. 87, 101 (1999) ("The Federal Circuit misconstrued the Markman II decision in an effort to justify a de novo standard of review.”). 
terpretation of Markman II. ${ }^{62}$ While Markman II clearly held that the Seventh Amendment did not require that claim construction be tried to juries, ${ }^{63}$ it was largely silent on the other points of disagreement among the Federal Circuit judges in Markman I. The other major criticism of Cybor regarding the scope of Markman II is that Cybor downplayed Supreme Court dicta implying that claim construction could implicate underlying factual inquiries. In Markman II, while struggling to classify claim construction, the Court stated: (1) that "construing a term of art following receipt of evidence" is a "mongrel practice," standard and a simple historical fact," ${ }^{65}$ and (3) that, in weighing expert testimony, "we expect [that] credibility determinations will be subsumed within the necessarily sophisticated analysis of the whole [patent] document." ${ }^{66}$ As these statements were essentially dicta, the Cybor majority easily downplayed the first two statements as "only prefatory comments" ${ }^{67}$ and the third as actually supporting its rule. ${ }^{68}$ After explaining away the Supreme Court's dicta, the majority made a brief concession to the viability of a narrow reading of Markman II, ${ }^{69}$

${ }^{62}$ See Cybor, 138 F.3d at 1463-64 (Mayer, J., concurring in the judgment); id. at 1473 (Rader, J., "dissenting from the pronouncements on claim interpretation in the en banc opinion, concurring in the judgment, and joining part IV of the en banc opinion"); $i d$. at 1478 (Newman, J., dissenting in part and expressing additional views). Judge Rader went further and insisted, as he had in Markman I, that both Markman cases presented only jury issues and that "this court has yet even to receive briefing and oral argument on the proper standard of review for a trial court's claim construction." Id. 1473 (Rader, J., dissenting in part); see also Markman I, 52 F.3d at 998 (Rader. J., concurring in the judgment) ("Whether claim construction can involve subsidiary fact issues is not before us.").

${ }^{63}$ Markman II, 517 U.S. at 384 n.9.

${ }^{64} I d$. at 378 . This "mongrel practice" reference appears to be the most frequently cited phrase to support the proposition that the Supreme Court considered claim construction to be a mixed issue of fact and law. Professor Rai notes this phrase in particular and argues that the Cybor decision "was necessary because the Supreme Court's disposition of the Markman case noted (though it did not specifically hold) that claim construction had factual underpinnings." Rai, supra note 61, at 1047-48 \& n.49; see also Moore, supra note 32, at 8 n.34 (noting that the Supreme Court referred to claim construction as a "mongrel practice"); Nard, supra note 10, at 364 (same); Hulse, supra note 61 , at 90 (same).

${ }^{65}$ Markman II, 517 U.S. at 388 (quoting Miller v. Fenton, 474 U.S. 104, 114 (1985)).

${ }^{66} I d$. at 389 (emphasis added).

${ }^{67}$ Cybor, 138 F.3d at 1455 .

${ }^{68}$ See id. at $1454 \&$ n.3, 1455 (construing this quote as downplaying the significance of credibility determinations in claim construction rather than acknowledging their existence).

${ }^{69}$ The majority acknowledges the plausibility of the view that Markman II did not 
but was quick to dismiss it and assert that "the Supreme Court's opinion conclusively and repeatedly states that claim construction is purely legal .... [O] ur conclusion in Markman I that claim construction is a matter of law was affirmed in all respects ...." ${ }^{70}$ Continuing to read Markman II as supporting its rule, the majority asserted that "[n]othing in the Supreme Court's opinion supports the view that the Court endorsed a silent, third option-that claim construction may involve subsidiary or underlying questions of fact." ${ }^{71}$ While these criticisms of what is essentially sweeping dicta under the rug are valid, they fail to explain why the dicta matter. Despite some questionable dicta, the Supreme Court ultimately affirmed Markman I and expressed confidence in the Federal Circuit and its role at the head of the patent system. $^{72}$

The more important distinction between Cybor and Markman IIand where many commentators seem to have missed the point-is that where the Supreme Court opinion may be read as having granted an exception to Rule 52(a) for policy reasons, the Federal Circuit tried to fit claim construction into Rule 52(a) by reclassifying it as a matter of law. The Supreme Court, in reaching its conclusion, found that "history and precedent provide[d] no clear answers," resorted to "functional considerations,", and ultimately decided as a matter of policy that there was "sufficient reason to treat construction of terms of art like many other responsibilities that we cede to a judge in the normal course of trial, notwithstanding its evidentiary underpinnings." ${ }^{, 74}$ Here the Supreme Court indirectly contradicted the Markman I analysis, and acknowledged that it was allocating claim construction to trial judges instead of juries for policy reasons. Further, the Supreme Court explicitly rejected the idea that its holding rested on the fact/law distinction. ${ }^{75}$ Despite the narrow wording of Markman II, the

address appellate review, but quickly dismisses this proposition and falls back on the assertion that, under the narrow view, Markman I was not disturbed by Markman II and remains good law. See id. at 1456 ("[E]ven this narrower view of Markman II leaves Markman I as the controlling authority regarding our standard of review.").

${ }^{70} I d$. at 1456 (emphasis added). Professor Duffy points out that, in the year Markman II was decided, Justice Stevens "expressly classified [Markman II] as a case involving "mixed questions of law and fact." Duffy, supra note 21, at $119 \mathrm{n} .41$ (quoting Gasperini v. Ctr. for Humanities, Inc., 518 U.S. 415, 443 (1996) (Stevens, J., dissenting)).

${ }^{71}$ Cybor, 138 F.3d at 1455 (emphasis added).

${ }^{72}$ Markman II, 517 U.S. at 391.

${ }^{73} \mathrm{Id}$. at 388 .

${ }^{74} I d$. at 390 (emphasis added).

${ }^{75}$ See, e.g., id. at 384 n.10 ("Because we conclude that our precedent supports clas- 
Federal Circuit read the opinion as accepting Markman I's strained explanations of the nature of claim construction. ${ }^{76}$ As Part III argues, this refusal by the Federal Circuit to admit what it was actually doing (reviewing a mixed question de novo) created a legal fiction that proved damaging to the patent law, especially since it carried the weight of an en banc opinion and the tacit approval of the Supreme Court. It is in this sense that the difference between Cybor and Markman II is important, and it is for this reason that Cybor has had a damaging effect on patent law.

Since Markman II, the Supreme Court has not granted certiorari on claim construction issues, and Cybor has converted Markman II's narrow, moderately worded opinion into a wholesale endorsement of de novo appellate review of claim construction. If the Supreme Court's repeated denial of certiorari petitions indicates its acceptance of Cybor, then this inconsistency is not bad in itself, as it results in the clear message that Markman I and Cybor, not Markman II, are the law on claim construction.

\section{B. Inconsistency with Federal Circuit Precedent- The "Canons of Claim Construction"}

Much has been written about the fact/law distinction, and it is beyond the scope of this Comment to discuss whether there is any significance to it beyond serving as a functional way of allocating work between judges and juries and determining the scope of appellate review. $^{77}$ For this analysis, I simply accept the proposition that, because the Federal Circuit is the central judicial authority on the patent law, it is to some extent the court's prerogative to label issues as fact or law as it sees fit. ${ }^{78}$ The problem, however, is that the issues that arise in

sifying the question as one for the court, we need not decide ... the extent to which the Seventh Amendment can be said to have crystallized a law/fact distinction .....").

${ }^{76}$ It is worth noting that Markman II never quoted or referred to Markman I or any other Federal Circuit case to support its reasoning. The only references to Federal Circuit cases are two references to Markman I that summarize the procedural history and disposition of the case. Markman II, 517 U.S. at 370, 375-76.

${ }^{77}$ For a more general and recent discussion of the meaning and practical implications of the fact/law distinction, see United States $v$. McKinney, 919 F.2d 405, 419 (7th Cir. 1990) (Posner, J., concurring); Ronald J. Allen \& Michael S. Pardo, The Myth of the Law-Fact Distinction, 97 Nw. U. L. REV. 1769 (2003).

${ }^{78}$ This is especially true because no other appellate court will have the opportunity to create a conflict by labeling the issue differently. Because Cybor was an en banc decision, it would not be a valid criticism to say that the decision was wrong because it contradicted the literal holding of previous claim construction opinions, though it is worth noting that Cybor represented a break with prior Federal Circuit 
patent law are all interrelated, and issue labeling must be done with regard for the overall consistency of the patent law. ${ }^{79}$ How the Federal Circuit chooses to define one issue may upset settled expectations for another. ${ }^{80}$ For claim construction, by the time Markman and Cybor were decided, the Federal Circuit had already labeled certain issues as questions of fact such that it was internally inconsistent to call claim construction a pure matter of law. Thus, by declaring that claim construction was a pure matter of law, the Federal Circuit cast doubt on the status of anticipation, obviousness, enablement, and expert witness testimony.

First, it is worth noting that one of the aspects of patent law that adds to its clarity is that the Federal Circuit and its predecessors have explained some issues by reference to other issues. For example, a defense to patent infringement is anticipation of the patent by prior art. Instead of delineating separate complex bodies of case law for infringement and anticipation, the Federal Circuit and its predecessor courts have simply held that " $[\mathrm{t}]$ hat which infringes, if later, would anticipate, if earlier." ${ }^{, 1}$ In this way, the courts have made it clear that anticipation and literal infringement are very closely related. Consistent with this, literal infringement and anticipation are both questions of fact and reviewed under the clear error standard. ${ }^{82}$ It would lead to

precedent. See, e.g., In re Donaldson Co., 16 F.3d 1189, 1192 (Fed. Cir. 1994) (Rich, J.) (holding that claim construction is reviewed de novo when there are no underlying factual issues); Key Mfg. Group, Inc. v. Microdot, Inc., 925 F.2d 1444, 1448 (Fed. Cir. 1991) (Rader, J.) (same); Perini Am., Inc. v. Paper Converting Mach. Co., 832 F.2d 581, 584 (Fed. Cir. 1987) (Markey, C.J.) (same), overruled in part on other grounds by Cardinal Chem. Co. v. Morton Int'l, 508 U.S. 83, 92 n.12 (1993).

${ }^{79}$ See, e.g., Nard, supra note 10 , at 356 (noting that the Markman I court, by addressing only the issue of whether a judge or jury should interpret claim language, unwittingly created confusion regarding whether a de novo standard should be used for reviewing such interpretations).

${ }^{80}$ Describing the relatedness of prosecution history estoppel and the doctrine of equivalents, Judge Rader noted that, "[1]ike the proverbial balloon, a pinch on the backside of the law disrupts symmetry on the front side." Festo Corp. v. Shoketsu Kinzoku Kogyo Kabushiki Co., 344 F.3d 1359, 1374 (Fed. Cir. 2003) (en banc) (Rader, J., concurring), cert. denied, 124 S. Ct. 2018 (2004), 124 S. Ct. 2019 (2004).

${ }^{81}$ Peters v. Active Mfg. Co., 129 U.S. 530, 537 (1889) (quoting Peters v. Active Mfg. Co., 21 F. 319, 321 (C.C.S.D. Ohio 1884)). The Federal Circuit has qualified this maxim to note that it applies only to literal infringement, but has otherwise consistently applied this maxim in its cases. See, e.g., Lewmar Marine, Inc. v. Barient, Inc., 827 F.2d 744, 747 (Fed. Cir. 1987) ("That which would literally infringe if later in time anticipates if earlier than the date of invention.").

${ }^{82}$ See Merck \& Co v. Teva Pharm. USA, Inc., 347 F.3d 1367, 1369 (Fed. Cir. 2003) (citing Lindemann Maschinenfabrik GMBH v. American Hoist \& Derrick Co., 730 F.2d 1452, 1458 (Fed. Cir. 1984)) (both cases holding that anticipation is a question of fact 
internal inconsistency and contradict settled doctrine if the Federal Circuit were to label one of the two issues as law without regard for the doctrinal relationship between the two concepts. Similarly, the courts have clearly delineated a logical relationship between anticipation by prior art and obviousness in light of prior art:

Though it is never necessary to so hold, a disclosure that anticipates un$\operatorname{der} \S 102$ also renders the claim invalid under $\S 103$, for anticipation is the epitome of obviousness. The reverse is not true, for the need to determine obviousness presumes anticipation is lacking. ${ }^{83}$

The courts have fashioned a different relationship between anticipation and obviousness-obviousness is a broader inquiry than anticipation, but it circumscribes the inquiry for anticipation, and it would upset expectations and internal consistency to change the nature of the anticipation inquiry without regard for the obviousness inquiry.

Claim construction is a similar situation in that the process has been made clearer by associating it with other aspects of patent litigation that have already been labeled as issues of fact. The process of claim construction has been explained primarily by limiting the sources which may be used in claim construction, and by creating certain "canons" of construction meant to guide the process. Some canons require the district court to preemptively perform inquiries that the Federal Circuit has definitively labeled as questions of fact.

For example, two of the "canons" of claim construction require the trial court to perform inquiries that are indistinguishable from the infringement and anticipation analyses. Where possible, the district court must construe the claims to include the inventor's device and also to exclude prior art. These principles are commonly stated as "a claim interpretation that would exclude the inventor's device is rarely

to be reviewed for clear error); see also Insituform Techs., Inc. v. Cat Contracting, Inc., 161 F.3d 688, 692 (Fed. Cir. 1998) (citing SRI Int'l v. Matsushita Elec. Corp. of Am., 775 F.2d 1107, 1125 (Fed. Cir. 1985) (en banc)) (both holding that infringement is a question of fact to be reviewed for clear error).

${ }^{83}$ Connell v. Sears, Roebuck \& Co., 722 F.2d 1542, 1548 (Fed. Cir. 1983) (emphasis added) (citation and internal quotation marks omitted); see also In re McDaniel, 293 F.3d 1379, 1385 (Fed. Cir. 2002) ("[A]nticipation is the epitome of obviousness." (internal quotation marks omitted)); In re Kalm, 378 F.2d 959, 962 (C.C.P.A. 1967) ("[A] complete description [is] but the ultimate or epitome of obviousness."). Professor Dreyfuss notes that the Federal Circuit has done a thorough and thoughtful job developing the problem of obviousness, and in its current form it still bears a significant resemblance to the anticipation analysis. See Dreyfuss, supra note 7, at 8-11 (discussing the Federal Circuit's evolving approach to the obviousness requirement). 
the correct interpretation," avoids ensnaring prior art if it is possible to do so." ${ }^{85}$ These principles preserve the notion that an inventor drafts claims with the intent of protecting her invention ${ }^{86}$ and the presumption that a patent is valid. ${ }^{87}$ To apply these principles to claim construction, the district court must compare the scope of its claim construction with prior art and with the inventor's device. The Federal Circuit has repeatedly stated that this type of inquiry is a question of fact. ${ }^{88}$ Thus, claim construction must involve underlying questions of fact, at least where a question arises as to whether the scope of the district court's claim construction excludes the inventor's device or unnecessarily includes prior art. Yet, the Federal Circuit has never meaningfully explained how the anticipation and infringement analyses are performed differently in the context of claim construction.

A third canon of claim construction is that:

Where there is an equal choice between a broader and a narrower meaning of a claim, and there is an enabling disclosure that indicates that the applicant is at least entitled to a claim having the narrower meaning, we consider the notice function of the claim to be best served by adopting the narrower meaning.

Application of this principle requires the trial court to decide whether there is an enabling disclosure that entitles the patentee to the narrower meaning. This enablement requirement has been labeled as a question of law that may implicate underlying factual inquiries. $^{90}$ Although not as glaring as the discrepancy noted above re-

${ }^{84}$ Modine Mfg. Co. v. United States Int'l Trade Comm'n, 75 F.3d 1545, 1550 (Fed. Cir. 1996); see also Interactive Gift Express, Inc. v. Compuserve Inc., 256 F.3d 1323, 1343 (Fed. Cir. 2001) (rejecting a proposed claim construction that would have excluded the preferred embodiment); Vitronics Corp. v. Conceptronic, Inc., 90 F.3d 1576, 1583 (Fed. Cir. 1996) (same).

${ }^{85}$ Harris Corp. v. IXYS Corp., 114 F.3d 1149, 1153 (Fed. Cir. 1997).

${ }^{86}$ See Hansen v. Colliver, 171 F. Supp. 803, 811 (N.D. Cal. 1959) ("The presumption is that a patentee, having the right to claim his whole invention, intended to do so." (citation omitted)), rev'd in part on other grounds, 282 F.2d 66 (9th Cir. 1960).

${ }^{87}$ See 35 U.S.C. $\$ 282$ (2000) (“A patent shall be presumed valid.”).

${ }^{88}$ See Markman I, 52 F.3d at 976 (surveying the relevant precedent and concluding that "the trier must judge whether the claims cover the accused device (a question of fact)" (quoting Envirotech Corp. v. Al George, Inc., 730 F.2d 753, 758 (Fed. Cir. 1984))); see also Ruiz v. A.B. Chance Co., 234 F.3d 654, 669 (Fed. Cir. 2000) ("Comparing the properly construed claims to the accused device is a question of fact reviewed for clear error.").

${ }^{89}$ Athletic Alternatives, Inc. v. Prince Mfg., Inc., 73 F.3d 1573, 1581 (Fed. Cir. 1996).

${ }^{90}$ See Union Pac. Res. Co. v. Chesapeake Energy Corp., 236 F.3d 684, 690 (Fed. 
garding anticipation and infringement law, applying this canon still requires the district court to perform an analysis that includes factfinding, although Cybor definitively holds that it does not. ${ }^{91}$

All three of the above-mentioned canons of claim construction have clarified the process of claim construction, but they have also defined the process by reference to certain inquiries that the Federal Circuit has already labeled as questions of fact. ${ }^{92}$ Declaring that claim construction has no underlying issues of fact has created an inconsistency between the Cybor rule and the settled understanding of the factual nature of the inquiries underlying claim construction.

Thus, by the time Cybor was decided, the Federal Circuit had already defined claim construction largely by connecting it with other issues in patent litigation. Just as the judge must do in deciding obviousness, anticipation, or enablement, she must perform certain factual inquiries en route to the conclusions of claim construction. By denying this fact, the Federal Circuit damaged the overall coherence of the patent law, which largely depends on its internal consistency. As the next section explains, this disturbance in doctrine has created problems in practice for litigants and district court judges.

Cir. 2001) ("As is often true of legal questions, however, the ultimate legal conclusion of enablement rests on factual underpinnings. When the district court's judgment on enablement rests on these factual underpinnings, this court reviews the decision for clearly erroneous findings of fact and errors of law.").

${ }^{91}$ See Cybor Corp. v. FAS Techs., Inc., 138 F.3d 1448, 1462 (Fed. Cir. 1998) (explaining that the analysis for understanding the meaning of claims does not involve fact finding).

${ }_{92}$ R. Polk Wagner and Lee Petherbridge point to empirical evidence showing that that the Federal Circuit's claim construction jurisprudence is moving toward what they term a "procedural" approach, wherein the court construes claims according to a formal process. R. Polk Wagner \& Lee Petherbridge, Is the Federal Circuit Succeeding? An Empirical Assessment of Judicial Performance, 152 U. PA. L. REV. 1105, 1150-51 (2004). Under the procedural approach, the court begins with the "plain meaning" as the presumptive interpretation of the claim. Any deviation from the plain meaning requires a strong justification, and is done according to a predetermined path of analysis through a hierarchy of interpretive sources (e.g., the written description, expert testimony, etc.). Id. at 1133-34. For an example of this approach, see Johnson Worldwide Assocs., Inc. v. Zebco Corp., 175 F.3d 985, 989-90 (Fed. Cir. 1999). The rise of the procedural approach may undermine the utility, and to some extent the validity of the "canons." This is not certain, however, and the canons often serve as "tiebreakers" whenever an interpretive process arrives at more than one viable construction, and are to that extent independent of any interpretive approach. See, e.g., Athletic Alternatives, 73 F.3d at 1581 (employing a "tiebreaker" rule where two equally plausible meanings for a claim term were possible). 


\section{THE EFFECTS OF THE CYBOR RULE}

Part II described the doctrinal consequences of Cybor. This Part traces the effects of the rule in practice. Because of the doctrinal inconsistency between Cybor and the Federal Circuit's precedents, the Federal Circuit has had to resort to strained logic to shoehorn claim construction into the confines of a purely legal issue. In other words, the problem with Cybor is not so much that the Federal Circuit decided for policy reasons to treat claim construction as an issue of law, but rather that, to justify its decision ex post, it began trying to force claim construction to behave as a purely legal issue. The results have shown that claim construction is, to some extent, an inherently factual issue. The results of this contradiction have included Federal Circuit remands for factfinding disguised as something else, a reluctance by some judges to apply the rule strictly, seepage of the Cybor legal fiction into issues beyond claim construction and, worst of all, confusion in the district courts. This Part describes these effects.

\section{A. Strained Logic and Federal Circuit Remands}

The most problematic and transparently contradictory aspect of the Federal Circuit's post-Cybor claim construction jurisprudence is its treatment of expert testimony and other extrinsic evidence offered in claim construction hearings. It is a general rule in federal litigation that a trial court's weighing of expert testimony is a credibility determination, an evidentiary finding of fact, and reviewed for clear error. ${ }^{93}$ In Cybor and Markman I, however, the majorities insisted that a trial judge's use of expert testimony geared toward claim construction is not a finding of fact. Basically, the explanation goes, because expert testimony is of limited use during claim construction (it may not be used to contradict intrinsic evidence), and because it is only used to

${ }^{93}$ See FED. R. CIV. P. 52(a) ("Findings of fact, whether based on oral or documentary evidence, shall not be set aside unless clearly erroneous, and due regard shall be given to the opportunity of the trial court to judge of the credibility of the witnesses."). As the Supreme Court has noted:

[W] hen a trial judge's finding is based on his decision to credit the testimony

of one of two or more witnesses, each of whom has told a coherent and fa-

cially plausible story that is not contradicted by extrinsic evidence, that find-

ing, if not internally inconsistent, can virtually never be clear error.

Anderson v. Bessemer City, 470 U.S. 564, 575 (1985); see also Amstar Corp. v. Envirotech Corp., 823 F.2d 1538, 1545 (Fed. Cir. 1987) ("When, as here, the evidence consists solely of competing expert opinions, we have no basis for overturning the district court's credibility determinations." (citing Anderson, 470 U.S. at 575)). 
assist the court in its understanding of the patent documents, the district court's use of such testimony is not a finding of fact. As the Federal Circuit stated in Markman I:

Through this process of construing claims by, among other things, using certain extrinsic evidence that the court finds helpful and rejecting other evidence as unhelpful ... the court is not crediting certain evidence over other evidence or making factual evidentiary findings. Rather, the court is looking to the extrinsic evidence to assist in its construction of the written document, a task it is required to perform. The district court's claim construction, enlightened by such extrinsic evidence as may be helpful, is still based upon the patent and prosecution history. It is therefore still construction, and is a matter of law subject to de novo review. ${ }^{94}$

This explanation belies the partiality of expert testimony. Although the Federal Rules of Evidence allow a district court to appoint an independent expert who might be better suited to this task, ${ }^{95}$ the courts typically allow the parties to appoint their own experts. ${ }^{96}$ This results in the same "battle of the experts" that occurs in medical malpractice and products liability cases and in the damages phase of many complicated civil suits. Patent litigants hire the most qualified expert they can to testify to a construction that suits their interest. When a district court judge agrees with the testimony of one expert over another in performing claim construction, the judge has credited that evidence over other evidence. ${ }^{97}$ To insist that this is not a credi-

${ }^{94}$ Markman I, 52 F.3d at 981 (footnote omitted).

${ }^{95}$ FED. R. EVID. 706.

96 See Rai, supra note 61, at 1048 \& n.48 (noting that a 1999 survey "found that trial courts considered extrinsic evidence in eighty-three percent of cases that required claim construction" (citing 1999 ABA Section of Intellectual Property Law, 1999 Markman Survey, 18 A.B.A. SEc. PUB. INTELL. Prop. L. 3 (2000))). For a detailed discussion of the possible role of court-appointed experts and other types of technical advisors in patent infringement trials, particularly on the issue of claim construction, see Si-Hung Choy, Comment, Judicial Education After Markman v. Westview Instruments, Inc.: The Use of Court-Appointed Experts, 47 UCLA L. REV. 1423 (2000).

${ }^{97}$ Judge Schwartz of the District of Delaware has made this observation as well, noting that " $[w]$ hen two experts testify differently as to the meaning of a technical term, and the court embraces the view of one, the other, or neither while construing a patent claim as a matter of law, the court has engaged in weighing evidence and making credibility determinations." Lucas Aerospace, Ltd. v. Unison Indus., 890 F. Supp. 329, 333 n.7 (D. Del. 1995). Similarly, Judge Rader has noted that:

Under the guise of setting standards for claim construction, this court instructs experienced trial judges that they may use experts to understand, but not to interpret, the claim terms. As a matter of logic, this instruction is difficult to grasp.... How will this perverse incentive to "hide the ball" improve appellate review? 
bility judgment, but that the judge has only found that expert's testimony more "helpful," is a semantic distinction that does not satisfactorily explain why the examination of expert testimony during claim construction is not a question of fact.

This type of strained logic is exemplary of the difficulty the Federal Circuit has had in keeping its practice consistent with the statement that claim construction never has any underlying factual inquiries. If it were indeed true that claim construction is a purely legal analysis, then it would seem that the Federal Circuit would always be able to perform claim construction de novo, and could avail itself of certain "extrinsic" sources, such as dictionaries, technical treatises, etc. $^{98}$ The patent documents, prosecution history, and other "intrinsic evidence" are all a matter of public record and almost always available to the Federal Circuit on appeal. Additionally, extrinsic sources such as treatises and dictionaries need not be part of the record below to be available to the Federal Circuit for use in claim construction. Despite this, the Federal Circuit has been occasionally unable to construe claims for itself and forced to remand cases to the district courts with instructions to collect and evaluate extrinsic evidence, sometimes in the form of competing expert witness testimony from the parties. Two exemplary cases are discussed briefly below.

In Apex Inc. v. Raritan Computer, Inc., ${ }^{99}$ the Federal Circuit found the evidence insufficient to perform claim construction and remanded the case to the district court to determine the meaning, to one skilled in the art, of the limiting terms "circuit," "interface," and "unit." 100 The Federal Circuit noted that, as with obviousness, to resolve the question of the understanding of one skilled in the art (which is a factual inquiry under the obviousness analysis ${ }^{101}$ ), "it is appropriate to look to extrinsic evidence, including but not limited to dictionaries and expert testimony to assist the trier of fact in under-

Cybor, 138 F.3d at 1474-75 (Rader, J., dissenting in part).

${ }^{98}$ William Rooklidge and Matthew Weil describe a case in which the Federal Circuit appears to have done its own independent patent and literature search to support its interpretation of a claim limitation. William C. Rooklidge \& Matthew F. Weil, Judicial Hyperactivity: The Federal Circuit's Discomfort with Its Appellate Role, 15 BERKELEY TECH. L.J. 725, 730-34 (2000) (describing In re Cortright, 165 F.3d 1353 (Fed. Cir. 1999)).

${ }^{99} 325$ F.3d 1364 (Fed. Cir.), cert. denied, 124 S. Ct. 922 (2003).

${ }^{100} \mathrm{Id}$. at 1375 .

${ }^{101}$ Graham v. John Deere Co. of Kansas City, 383 U.S. 1, 17 (1966) (stating that "[w] hile the ultimate question of patent validity is one of law," the non-obviousness requirement "lends itself to several factual inquiries," including "the level of ordinary skill in the pertinent art"). 
standing the evidence." ${ }^{102}$ The panel seemed aware of the inherent contradiction, but refused to acknowledge directly that it was remanding for factfinding. The court stated that, " $[\mathrm{w}]$ hile this court is plainly aware that claim construction is a question of law, we decline to construe every claim limitation because the record has not been sufficiently developed." 103

In NeoMagic Corp. $v$. Trident Microsystems, Inc., ${ }^{104}$ despite the fact that both parties offered evidence, the Federal Circuit was similarly unable to determine on its own "whether or not one of skill in the art would understand that a power supply is designed to provide a constant voltage to a circuit." 105 Although the Federal Circuit reiterated that claim construction is a matter of law and subject to de novo review, it was forced to remand the case to the district court. Further, the court specifically ordered an evidentiary hearing with competing expert testimony to resolve the issue. The court stated that "we think that this matter can only be resolved by further evidentiary hearings, including expert testimony, before the district court."106

In both of these cases, and in several others, ${ }^{107}$ the inquiries underlying claim construction have been so definitively factual that the Federal Circuit has been forced to remand the cases to the district courts for further weighing of evidence. These remands for "lawfinding" and consideration of expert testimony with regard to its "helpfulness" illustrate the difficulty of applying the Cybor holding with a straight face. ${ }^{108}$

102 Apex Inc., 325 F.3d at 1374 (emphasis added).

${ }^{103} I d$.

${ }^{104} 287$ F.3d 1062 (Fed. Cir. 2002).

${ }^{105} I d$. at 1074 .

${ }^{106} I d$. (emphasis added). On remand, the magistrate judge held an evidentiary hearing that included competing expert testimony and construed the claims based on the patent documents, dictionaries, and the testimony of the experts. NeoMagic Corp. v. Trident Microsystems, Inc., 110 Fed. Appx. 103, 2003 WL 21076779, at*1-12 (D. Del. May 9, 2003), aff'd, No. 04-1046, 2004 WL 1799404 (Fed. Cir. Aug. 5, 2004).

${ }_{107}$ See, e.g., Kumar v. Ovonic Battery Co., 351 F.3d 1364 (Fed. Cir. 2003) (remanding for consideration of extrinsic evidence to resolve claim construction inquiries); Verve, LLC v. Crane Cams, Inc., 311 F.3d 1116, 1120 (Fed. Cir. 2002) (same); Pall Corp. v. PTI Techs., Inc., 259 F.3d 1383, 1394 (Fed. Cir. 2001) (remanding the case for claim construction inquiries), vacated by 535 U.S. 1109 (2002); Advanced Cardiovascular Sys., Inc. v. Scimed Life Sys., Inc., 261 F.3d 1329, 1344 (Fed. Cir. 2001) (remanding the case for claim construction issues and noting that "extrinsic evidence will be particularly helpful in this case when construing the claims and properly determining what it means to someone skilled in the art to require the connecting elements to be 'generally parallel' to each other" (emphasis added)).

${ }^{108}$ A more accurate description of what is actually happening in these cases, and a clearer directive to the district courts, appears in Moeller v. Ionetics, Inc., 794 F.2d 653, 
As discussed above, the district courts receive contradictory signals from a reviewing court that remands a case for further development of the record but not for factfinding.

\section{B. Reluctance to Apply the Rule Strictly}

Further evidence that Cybor is an ill-advised rule is the fact that some federal judges have been reluctant to apply it strictly. Though ostensibly trying to soften the blow of a drastic new rule, Judge Bryson's and Judge Plager's concurring opinions in Cybor ${ }^{109}$ clouded the application of the rule even further. In the years following Cybor, a minor line of cases developed that cited these concurring opinions and made it less clear than before to what extent the Federal Circuit intended to apply its de novo reviewing power.

Although the Cybor majority stated definitively that claim construction is to be reviewed without deference, Bryson and Plager seemingly sought to soften the blow of the drastic new rule announced by the majority by providing reassurances that the Federal Circuit will still assign weight to district court opinions as a matter of common sense. Judge Bryson argued that de novo review does not necessitate complete disregard of district court opinions, ${ }^{110}$ and Judge Plager asserted that the degree of deference afforded to district court opinions would be flexible in its application, depending on the care with which the claim construction was done and the evidence was used to support it. ${ }^{111}$ Beginning with Key Pharmaceuticals v. Hercon Laboratories Corp. ${ }^{112}$ which was decided on November 25, 1998, just six months after $C y$ bor-a few post-Cybor opinions began to reference the concurring opinions $^{113}$ and profess that "[o]ur standard of review of claim con-

657 (Fed. Cir. 1986) ("On remand, the district court should be aware that, although claim construction is a legal question, underlying fact disputes may arise pertaining to extrinsic evidence that might preclude summary judgment treatment of claim construction."), overruled by Markman I, 52 F.3d 967 (Fed. Cir. 1995).

${ }^{109} 138$ F.3d at 1462 (Plager J., concurring); id. at 1463 (Bryson, J., concurring).

${ }^{110}$ See id. at 1463 (Bryson, J., concurring) (acknowledging that "as to particular legal issues lower tribunals have special competence and their judgments on those legal issues should be accorded significant weight").

111 See id. at 1462 (Plager, J., concurring) (explaining that a trial judge's view will carry weight on appeal, but the weight will depend upon "the care . . with which that view was developed, and the information on which it was based").

112161 F.3d 709 (Fed. Cir. 1998) (Plager, J.).

113 See, e.g., Pieczenik v. Dyax Corp., 76 Fed. Appx. 293, 296, 2003 WL 22203775, at *3 (Fed. Cir. Sept. 23, 2003) (Rader, J.) (citing Key Pharmaceuticals and affirming the district court's summary judgment of noninfringement because the Federal Circuit's claim construction, though different from the district court's, led to the same result), 
struction is now firmly established: we exercise independent review. However, we do not start from scratch; rather we begin with and carefully consider the trial court's work."

These cases have not so much undercut Cybor as they have undermined its clarity. It was readily apparent to all of the judges in Cybor that the Federal Circuit was reserving for itself more power to review than it had previously, and that it was adopting a hard-line approach to appellate review of claim construction. The concurring opinions amounted to little more than a promise to read the district court opinions and to use the new power thoughtfully. ${ }^{115}$ In one sense, by promising to consider the district courts' claim construction orders, these opinions attempt to strike a compromise between unapologetic de novo review and an overly restrictive standard of deference. On the other hand, the concurrences contradict the clear holding of $\mathrm{Cy}$ bor and seem to disguise the fact that the Federal Circuit's case law at that point required no deference to the district courts. In either case, the concurrences seem to have acquired very little precedential weight in the case law and do little more than confuse the message sent to district courts and potential litigants.

\section{Seepage into Indefiniteness Law}

During the years following Cybor, the reclassification of claim construction began to seep into other areas of the Federal Circuit's case law, most notably indefiniteness. In 1998, the court held in Personalized Media Communications, L.L.C. v. International Trade Commission ${ }^{116}$ that "determination of claim indefiniteness is a legal conclusion that is drawn from the court's performance of its duty as the construer of

cert. denied, 124 S. Ct. 1715 (2004); Apple Computer, Inc. v. Articulate Sys., Inc., 234 F.3d 14, 20 (Fed. Cir. 2000) (Archer, J.) (citing Cybor and Key Pharmaceuticals, and reviewing claim construction for something similar to clear error); Dow Chem. Co. v. United States, 226 F.3d 1334, 1338 (Fed. Cir. 2000) (Archer, J.) (citing Cybor and Key Pharmaceuticals and reversing the Court of Federal Claims' claim construction); Schering Corp. v. Amgen Inc., 222 F.3d 1347, 1351 (Fed. Cir. 2000) (Rader, J.) (citing Key Pharmaceuticals and affirming the district court's claim construction).

${ }^{114}$ Key Pharm., 161 F.3d at 713 (citing Cybor, 138 F.3d at 1462-63 (Plager and Bryson, JJ., concurring separately) (internal citations omitted)).

${ }^{115}$ Matthew Hulse points out that the concurring opinions provide no explanation for the need to "create a fiction that credibility is simply a tool of legal construction and not, as generally accepted, a factual inquiry." Hulse, supra note 61, at 100 (footnote omitted).

${ }^{116} 161$ F.3d 696 (Fed. Cir. 1998). 
patent claims," ${ }^{117}$ and stated in 1999, in Atmel Corp. v. Information Storage Devices, Inc. ${ }^{118}$ that a determination of indefiniteness is reviewed de novo "like claim construction." 119 Despite this apparent intention to withdraw recognition of the existence of factual inquiries underlying indefiniteness law, such an interpretation of Atmel and Personalized Media met resistance from some district court judges who believed that the Federal Circuit had previously recognized that indefiniteness could involve underlying questions of fact. ${ }^{120}$

Despite this apparent contradiction, the Federal Circuit ruled affirmatively in 2001, in Exxon Research E Engineering Co. v. United States, ${ }^{121}$ that indefiniteness was sufficiently tied to claim construction that it could not involve underlying questions of fact either. ${ }^{122}$ In Exxon Research, the Court repeated the counterintuitive explanation that it used in Markman I to declare claim construction a pure matter of law:

[A]lthough a court may consider or reject certain extrinsic evidence in resolving disputes en route to pronouncing the meaning of claim language, "the court is not crediting certain evidence over other evidence or making factual evidentiary findings. Rather, the court is looking to the extrinsic evidence to assist in its construction of the written document ...."123

Further adding to the confusion over indefiniteness law, some recent Federal Circuit opinions have ignored the precedents tying indefiniteness to Cybor. For example, in BJ Services Co. v. Halliburton Energy Services, Inc. ${ }^{124}$ decided in 2003, the court noted that, although indefiniteness is generally reviewed de novo, "[1]ike enablement,

117 Id. at 705 .

118198 F.3d 1374 (Fed. Cir. 1999).

${ }^{119} I d$. at 1378 (citing Personalized Media and Cybor).

${ }^{120}$ See Sys. Mgmt. Arts Inc. v. Avesta Techs., Inc., 137 F. Supp. 2d 382, 399-400 (S.D.N.Y. 2001) (collecting six district court opinions following this reasoning, and explaining that "while the Federal Circuit has often stated that the indefiniteness inquiry is 'drawn from' the district court's role as a construer of patent claims, [it] has not expressly held that these inquiries are one and the same, nor that the indefiniteness inquiry can not involve underlying questions of fact" (citation omitted)).

121265 F.3d 1371 (Fed. Cir. 2001).

122 See id. at 1376 (citing Cybor, reiterating some of its reasoning, and rejecting Exxon's argument that "the issue of indefiniteness turns on an underlying factual dispute that should not have been resolved as a matter of law on summary judgment").

${ }^{123}$ Id. (quoting Markman I, 52 F.3d 967, 981 (Fed. Cir. 1995) (en banc)).

124338 F.3d 1368 (Fed. Cir. 2003), cert. denied, 124 S. Ct. 1878 (2004). 
definiteness, too, is amenable to resolution by the jury where the issues are factual in nature., ${ }^{125}$

The doctrinal inconsistency of Cybor has thus infected the issue of indefiniteness as well, in a way that has expanded the Federal Circuit's reviewing power while sending more mixed messages to district courts and potential litigants. As noted above, claim construction is linked to many other issues in patent litigation, ${ }^{126}$ and this effect could easily spread to other issues.

\section{Confusion in the District Courts}

A fourth consequence of the Federal Circuit's casting of claim construction as a purely legal matter is that trial courts have reached bizarre conclusions when attempting to force claim construction to behave as a purely legal issue. For example, there are a handful of cases in the Northern District of New York in which district judges have denied parties' requests for discovery in patent cases on the grounds that any fact-related discovery would be irrelevant to claim construction, because claim construction is a pure matter of law. ${ }^{127}$ Thus district courts have decided claim construction and later granted summary judgment of either infringement or noninfringement, without allowing the parties to conduct full discovery. ${ }^{128}$ This is a bizarre

${ }^{125} I d$. at 1372 (reviewing the jury verdict for substantial evidence).

${ }^{126}$ See supra Part II.B (explaining the interrelation between claim construction and other issues in patent infringement litigation).

${ }^{127}$ See, e.g., Envirco Corp. v. Clestra Cleanroom Inc., 49 U.S.P.Q.2d (BNA) 1838, 1840, No. 98-CV-120, 1998 WL 809369 (N.D.N.Y. Nov. 4, 1998) (citing Canton BioMedical v. Integrated Liner Techs., Inc., 19 F. Supp. 2d 22 (N.D.N.Y. 1998), aff'd, 216 F.3d 1367 (Fed. Cir. 2000), and denying Envirco's motions to compel discovery and granting summary judgment of noninfringement), vacated by 209 F.3d 1360 (Fed. Cir. 2000); Cortland Line Co. v. Orvis Co., 49 U.S.P.Q.2d (BNA) 1745, No. 97-CV-1294, 1998 WL 743722 (N.D.N.Y. Oct. 7, 1998) (citing Canton Bio-Medical, denying Cortland's discovery requests, and granting Orvis's motion for summary judgment of noninfringement), vacated in part by 203 F.3d 1351 (Fed. Cir. 2000); Canton Bio-Medical, Inc., 19 F. Supp. 2d at 27 (N.D.N.Y. 1998) (denying discovery requests by the same logic and granting summary judgment on noninfringement by reason of prosecution history estoppel).

${ }^{128}$ What is important here is not the sequence of discovery, but the grounds on which it was affected in these cases in the Northern District of New York. While the pretrial process depends somewhat on judicial discretion, this discretion should not be informed by an extension of the logical implications of the Cybor rule. Some jurisdictions, such of the Northern District of California, have avoided this and many other problems attendant to discovery in patent cases by adopting local rules specifying how discovery in patent cases is to be conducted. N.D. CAL. CIV. LOCAL R. 16-9 to -10. Such measures have their own costs, such as adding rigidity to the process at the possible expense of efficiency and limiting the discretion of judges. Cf. Hon. Roderick R. 
result, but it follows logically from the Federal Circuit's explanation of claim construction as a pure question of law. This result is symptomatic of a larger general pattern of unpredictability in the trial courts. Prior to trial, litigants do not know how far a trial judge will extend the logical implications of casting claim construction as a pure question of law into decisions on other matters.

\section{E. Conclusion}

Attempts to force claim construction to behave as a purely legal issue have shown that much of the time it is impossible to do so. Because many of the issues underlying and relating to claim construction are inherently questions of fact, it creates an internal inconsistency when a court tries to declare or explain that they are only questions of law. The main result of this inconsistency has been the sending of mixed messages to trial courts. The Federal Circuit, for example, has remanded claim construction issues for factfinding, but, bound by its holding in Cybor, the court has had to refrain from using the word "fact," giving district courts convoluted and contradictory descriptions of what to do. Additionally, some Federal Circuit judges have strayed from this strict approach and applied a softened version of the Cybor rule that contradicts its holding and only adds to the mixed messages that district courts receive regarding claim construction. This doctrinal confusion has seeped into the Federal Circuit's cases on indefiniteness and had bizarre results in the district courts. These results cast doubt on the continued workability of the Cybor rule. It appears that in Cybor the Federal Circuit intended only to resolve the issue of appellate review, but its justification for that result has threatened the internal consistency of patent law and the very uniformity that Cybor was supposed to protect.

\section{REWRITING CYBOR}

As noted above, Professor Dreyfuss identifies one of the major problems facing the Federal Circuit as the need to find a way to reverse district court opinions that are inconsistent with its teachings. ${ }^{129}$

McKelvie, Side Bar: Markman v. Westview and Procedures for Construing Claims, in PRINCIPLES OF PATENT LAW, supra note 8, at 854, 854-55 (describing the procedural difficulties of Markman hearings and the benefits of having discretion to decide the timing of pretrial activities).

${ }^{129}$ Dreyfuss, supra note 7, at 50; see also supra note 37 (noting that, feeling itself constrained by Rule 52(a) at the time of Panduit Corp. v. Dennison Manufacturing Co., 
Although commentators have criticized the Federal Circuit for appellate factfinding, and made numerous proposals to place greater expertise at the trial court level (including special courts, ${ }^{130}$ special judges, ${ }^{131}$ expert juries, ${ }^{132}$ and greater use of technical advisors ${ }^{133}$ ), none of these proposals has taken hold. By 1998, when Cybor was decided, the Supreme Court had done little since 1987 to guide or rein in the Federal Circuit, ${ }^{134}$ and had not taken the opportunity afforded it in Markman II to directly address the points disputed by the judges in Markman $I^{135}$ Further, the commentary and available empirical data indicated that district courts were not absorbing all of the teachings of the Federal Circuit, particularly with respect to claim construction. $^{136}$ In short, the Federal Circuit was on its own in 1998, with little

810 F.2d 1561, 1569 (Fed. Cir. 1987), the Federal Circuit was limited to noting noncontrolling errors in judgments below that it was forced to affirm).

${ }^{130}$ See, e.g., John B. Pegram, Should There Be a U.S. Trial Court with a Specialization in Patent Litigation?, 82 J. PAT. \& TRADEMARK OFF. SOC'Y 765 (2000) (discussing proposals for U.S. trial courts with a specialization in patent litigation); Arti K. Rai, Specialized Trial Courts: Concentrating Expertise on Fact, 17 BERKELEY TECH. L.J. 877 (2002) (proposing the creation of a specialized trial court to which the Federal Circuit would refer on questions of fact); see also Dreyfuss, supra note 7, at 2 n.4 ("[S]ome ... would extend the concept of expert adjudication to the establishment of 'science courts' to assist society in grappling with new technologies." (citing Arthur Kantrowitz, Proposal for an Institution for Scientific Judgment, 156 SCI. 763 (1967); James A. Martin, The Proposed "Science Court," 75 MICH. L. REV. 1058 (1977))).

${ }^{131}$ See, e.g., Edward V. Di Lello, Note, Fighting Fire with Firefighters: A Proposal for Expert Judges at the Trial Level, 93 COLUM. L. REV. 473, 473, 490-91 (1993) (proposing "the creation of a new adjunct judicial office for magistrate judges who are specialists in technical fields").

${ }^{132}$ See generally Michael A. Fisher, Going for the Blue Ribbon: The Legality of Expert Juries in Patent Litigation, 2 Colum. SCI. \& TECH. L. REV. 2 (2000-2001), at http://www.stlr.org/cite.cgi?volume=2\&article=2 (last visited Nov. 4, 2004) (discussing the feasibility and constitutional implications of a proposal to empanel special juries of scientifically trained people for patent cases).

${ }^{133}$ See generally Choy, supra note 96 (discussing the use of expert witnesses and technical advisors).

${ }^{134}$ See generally Duffy, supra note 4 (discussing the Supreme Court's withdrawal from deciding patent controversies); Janis, supra note 4 (same).

${ }^{135}$ The late Judge Nies, in an article written shortly after the Markman II decision, disagreed with this assessment, and argued that the Supreme Court considered the dissenting opinions and resolved the dispute in favor of the majority. See Hon. Helen Wilson Nies, Dissents at the Federal Circuit and Supreme Court Review, 45 AM. U. L. REv. 1519, 1523 (1996) ("While the majority prevailed, Judge Newman's dissent performed the extraordinary service of delineating a scholarly basis for disagreement.").

${ }^{136}$ See Chu, supra note 32, at 1098-99 (noting the high reversal rate by the Federal Circuit of district court claim construction); Moore, supra note 32, at 2 (same). Perhaps even more relevant to Markman, the commentary and empirical data also indicated a much greater problem with juries. See id. at 3 n.5 (noting that studies have shown that juries often decide patent cases based on "bias or emotion rather than ra- 
more than a permissively worded opinion by the Supreme Court and a mandate to make patent law more uniform. The logical solution at that point was to assert greater control, and to make a bright-line rule that would clear away confusion and result in greater uniformity. ${ }^{137}$ As I have argued above, Cybor has had the complete opposite effect and has failed to live up to its promise because of its inconsistency with the rest of patent law.

In this final section, I offer two possible solutions. The first would be for the Federal Circuit to abandon Cybor altogether and treat claim construction as a mixed question of law and fact, much like it already treats obviousness and other issues. The Federal Circuit could address confusion in claim construction by making more bright-line rules that address how the process itself is conducted, and continue to refine its methods of review to make the law clearer. The second approach would be to leave Cybor as good law, but to try to cabin its effects by explaining its holding differently. The Federal Circuit would state clearly that it treats claim construction as a pure legal issue for the limited purpose of appellate review, but it does not purport to label all issues underlying claim construction as pure legal issues. This would be a minor change of course, and would attenuate all of the bad effects described in this Comment. Whichever approach the Federal Circuit takes, it should proceed with regard for how its decisions will affect settled expectations.

\section{A. Solution 1: Overrule Cybor}

If the Federal Circuit took the issue of appellate review of claim construction en banc, it would be relatively simple to overrule Cybor and any other cases to the extent that they derecognized the existence

tionality or merit," and tend not to "dissect issues"); Gregory D. Leibold, Comment, In Juries We Do Not Trust: Appellate Review of Patent-Infringement Litigation, 67 U. COLO. L. REV. 623, 624 (1996) (noting that other common critiques of juries are that they have an excessively high regard for the patent office and that they cannot understand the technology or the legal standards).

${ }^{137}$ Professor Duffy argues for this interpretation, stating that " $[\mathrm{t}]$ he majority's holding in favor of de novo review must be viewed as an implicit determination that the need for uniformity outweighs the efficiency costs of more vigorous appellate review." Duffy, supra note 21, at 123. While Cybor has not produced the promised uniformity, the choice between de novo review and deferential review of claim construction (or any other issue) in this case is a choice between putting additional pressure on district courts to write better orders (to avoid reversal) and putting additional pressure on the Federal Circuit to make its standards clearer and easier to apply. Professor Moore described this as a choice between accuracy and certainty. See Moore, supra note 32 , at $27-31$. 
of factual inquiries underlying claim construction. The Federal Circuit would return to reviewing district court claim construction by trying to parse all of the underlying issues as questions of fact or law and according deference or not when appropriate. This would place pressure on the Federal Circuit to continue to refine its approach to claim construction and to clarify how district courts are to proceed. For example, if the Federal Circuit could define claim construction as a clear step-by-step process, similar to the approach the panel took in Johnson Worldwide Associates, Inc. v. Zebco Corp. ${ }^{138}$ then it could review each step either de novo or for clear error and avoid sending mixed messages to the district courts. Mixed review is similar to the approach that the Federal Circuit takes to obviousness, and as Chief Judge Markey recognized a long time ago, deference and meaningful guidance to the district courts are not mutually exclusive: The court can continue to note noncontrolling misstatements of law in decisions it affirms, and it can note harmless errors without reversing a district court's disposition. $^{139}$

Further, the Federal Circuit has used methods other than aggressive appellate review to make its law on claim construction clearer. It has articulated several canons of claim construction to assist the district courts. ${ }^{140}$ The Federal Circuit has also made clear rules about certain terms that arise frequently in claim construction. For example, it is now settled that the word "comprising" as a transition in a patent claim means that the claimed invention includes, but is not limited to, the elements in the claim. ${ }^{141}$ The Federal Circuit has also established a series of presumptions in claim construction to clarify the process, such as that the indefinite article "a" or "an" in a patent claim is pre-

${ }^{138} 175$ F.3d 985 (Fed. Cir. 1999). As Wagner and Petherbridge note, the Federal Circuit has at least two primary approaches to the methodology of claim construction, and Johnson Worldwide is exemplary of the "procedural" approach, in which the Federal Circuit has delineated a hierarchy of interpretive sources in claim construction to resolve situations where the district courts receive conflicting evidence. The procedural approach is much clearer and promises to provide more predictable results than the "holistic" approach. See generally Wagner \& Petherbridge, supra note 92.

${ }^{139}$ Panduit Corp. v. Dennison Mfg. Co., 810 F.2d 1561, 1567 (Fed. Cir. 1987) (Markey, C.J.) ("To contribute to consistency ... this court has affirmed judgments while noting noncontrolling misstatements of law ....").

${ }^{140}$ See supra Part II.B (detailing the rules set forth by the Federal Circuit to guide lower courts in issues of claim construction).

${ }^{141}$ See Robert C. Faber, Landis on Mechanics of Patent Claim Drafting, at $\S 7$ (4th ed. 1996) ("The word 'comprises' has been construed to mean in patent law, 'including the following elements but not excluding others.'" (internal citations omitted)). 
sumed to mean "one or more," 142 and that a claim element using the word "means" is presumed to be a means-plus-function claim under 35 U.S.C. $\S 112$, para. 6 , while an element that does not use the word "means" is not. ${ }^{143}$ All of these decisions by the Federal Circuit represent steps toward greater clarity and uniformity, and remain viable whether the Federal Circuit keeps or discards Cybor.

Reversing Cybor would give the district courts more responsibility in some cases to do claim construction correctly, and would place more pressure on the Federal Circuit to clarify its teachings. It would make appellate review of claim construction more complicated, in that the court would have to carefully parse factual and legal issues, but no court is better situated to do this than the Federal Circuit itself.

\section{B. Solution 2: Explain Cybor and Rein It In}

A second, less drastic solution, and one that may fit more neatly into the limited way in which the court has agreed to address the issue in Phillips, ${ }^{144}$ is to leave Cybor as good law to the extent that the Federal Circuit would continue to review claim construction de novo, but to disclaim those parts of the opinion in which the court states that claim construction is always a purely legal issue. ${ }^{145}$ This would be a minor adjustment and would attenuate the effects described in Part III. The Federal Circuit would state that, while claim construction may implicate factual issues, the court will treat claim construction as a purely legal issue because, as a matter of policy, it is inefficient and counter-

${ }^{142}$ See, e.g., KCJ Corp. v. Kinetic Concepts, Inc., 223 F.3d 1351, 1356 (Fed. Cir. 2000); AbTox, Inc. v. Exitron Corp., 122 F.3d 1019, 1023 (Fed. Cir. 1997); N. Am. Vaccine, Inc. v. Am. Cyanamid Co., 7 F.3d 1571, 1575-76 (Fed. Cir. 1993).

${ }^{143}$ See, e.g., York Prods., Inc. v. Cent. Tractor Farm \& Family Ctr., 99 F.3d 1568, 1574 (Fed. Cir. 1996). Whether a claim is designated as a "means-plus-function" claim under 35 U.S.C. $\$ 112$, para. 6 is important because means-plus-function claims are construed differently from other claims, and explicitly incorporate limitations of the specification into their scope.

${ }^{144}$ Phillips v. AWH Corp., 376 F.3d 1382 (Fed. Cir. 2004) (per curiam).

${ }^{145}$ In a footnote in a recent en banc opinion, Festo Corp. v. Shoketsu Kinzoku Kogyo Kabushiki Co., 344 F.3d 1359, 1368 n.3 (Fed. Cir. 2003) (en banc), cert. denied, 124 S. Ct. 2018 (2004), 124 S. Ct. 2019 (2004), the majority stated that "[w]e recognize that rebuttal of the presumption may be subject to underlying facts .... Nonetheless, the resolution of factual issues underlying a legal question may properly be decided by the court." (citation to Markman I omitted). While this may be an indication that the Federal Circuit has ceased to deny the existence of factual inquiries underlying claim construction, an indirect acknowledgment slipped into an en banc footnote only serves to cloud the issue further. Without a more strongly affirmative statement of what the Federal Circuit believes claim construction to be, the frequently cited holding of Cybor will carry more weight than a somewhat ambiguous footnote to the contrary. 
productive to parse the attendant legal and factual questions. Although this explanation might raise problems with Federal Rule of Civil Procedure 52(a), the Federal Circuit could bolster the opinion with the Supreme Court's statement in Markman II that it expected that factual questions would "be subsumed within the necessarily sophisticated analysis of the whole [patent] document."146 Thus, the Federal Circuit would acknowledge that its classification of claim construction as a purely legal issue is a convenient legal fiction meant to facilitate appellate review and nothing more. This would send a much clearer message to the district courts, and would more accurately describe what actually happens when the Federal Circuit reviews claim construction. Just as other legal fictions, such as implied contracts, are useful in limited circumstances, ${ }^{147}$ the fiction of claim construction as a purely legal issue is useful only for the purpose of appellate review. This approach would represent a scaling back of Cybor's scope, but would preserve its holding. ${ }^{148}$ And, as stated above, the Federal Circuit could continue to pursue other approaches for improving clarity and uniformity in claim construction.

${ }^{146}$ Markman II, 517 U.S. 370, 389 (1996). Professor Duffy notes that Rule 52(a) might not even be an impediment to this approach because it does not explicitly address mixed questions of fact and law, and he argues that the regional circuits' approach to this issue is not uniform. See Duffy, supra note 21, at 120-21.

${ }^{147}$ The common law enforces quasi-contractual obligations to compensate certain parties in the interest of justice, but does not construe quasi-contracts as true contracts because they lack certain contractual elements (e.g., offer and acceptance). 1 SAMUEL WiLLISTON \& RICHARD A. LORD, A TREATISE ON THE LAW OF CONTRACTS § 1:6 (4th ed. 1990); cf. Cotnam v. Wisdom, 104 S.W. 164, 165 (Ark. 1907) (discussing an implied contract, "where, in point of fact, there was no contract, no mutual understanding, and so no promise," and noting that such a construct "is doubtless a legal fiction"). Similarly, the Federal Circuit would state that it treats claim construction as a purely legal issue for policy reasons related to appellate review, but does not expect it to act like a purely legal issue for other purposes, such as remands for factfinding. There is nothing inherently wrong with calling a tail a leg for limited purposes. The problems arise when one subsequently expects the tail to do all of the things that legs do, like supporting one's weight.

${ }^{148}$ Wagner, Petherbridge, and Duffy argue that Cybor is best viewed as a reinforcement of the Federal Circuit's institutional status as the authoritative actor in the patent system, particularly for claim construction. Duffy, supra note 21, at 123; Wagner \& Petherbridge, supra note 92, at 1124. The solution outlined in this subsection would actually support this idea, because by stripping away all of the superfluous justifications, the Federal Circuit would say, essentially, that the holding of Cybor is based solely on institutional reasons, rather than on the idea that certain factual inquiries become legal inquiries in the context of claim construction. 


\section{CONCLUSION}

Cybor has been a failure in practice because it is so inconsistent with the settled law on so many issues relating to claim construction that it is impossible to apply its holding in practice without sending contradictory messages. By labeling claim construction as a pure issue of law, and then trying to force the underlying issues to behave as purely legal issues, the Federal Circuit drew an ill-advised bright line that threatens to undermine the progress that the court has made toward increasing uniformity and clarity in patent law. The strong dissents in Cybor, the bizarre results in the Federal Circuit and in the district courts, the minor defections by some judges, and the inconsistency with Federal Circuit and Supreme Court precedent are all evidence that Cybor was wrongly decided, and that the Federal Circuit should retreat from Cybor's approach. 